\title{
In Vitro Anticancer Activity of Imperata cylindrica Root's Extract toward Human Cervical Cancer and Identification of Potential Bioactive Compounds
}

\author{
Paul Nayim $\mathbb{D}^{1},{ }^{1,2}$ Krishna Sudhir, ${ }^{2}$ Armelle T. Mbaveng $\left(\mathbb{D},{ }^{1}\right.$ Victor Kuete $\mathbb{D}^{1},{ }^{1}$ \\ and Mukherjee Sanjukta $\mathbb{D D}^{2}$ \\ ${ }^{1}$ University of Dschang, Department of Biochemistry, P.O. Box 1499 Bafoussam, Dschang, Cameroon \\ ${ }^{2}$ National Centre for Biological Sciences (NCBS), Tata Institute of Fundamental Research (TIFR), Bellary Road, Bangalore, \\ 560065 Karnataka, India
}

Correspondence should be addressed to Armelle T. Mbaveng; armkuete@yahoo.fr, Victor Kuete; kuetevictor@yahoo.fr, and Mukherjee Sanjukta; msanjukta10@gmail.com

Received 12 July 2021; Accepted 30 September 2021; Published 18 October 2021

Academic Editor: Juliana Mozer Sciani

Copyright (c) 2021 Paul Nayim et al. This is an open access article distributed under the Creative Commons Attribution License, which permits unrestricted use, distribution, and reproduction in any medium, provided the original work is properly cited.

Imperata cylindrica is traditionally used to cure several diseases including cancer, wounds, and hypertension. The present study was designed to investigate the anticancer activity of the methanolic root extract of I. cylindrica (IC-MeOH). The water-soluble tetrazolium-1 and colony formation assays were used to check the proliferation ability of the cells. Cell apoptosis and cell cycle were measured by flow cytometry-based fluorescence-activated cell sorting. The ultrahigh-performance liquid chromatography-high-resolution mass spectrometry (UHPLC-HRMS) analysis was used for the metabolites profiling of IC$\mathrm{MeOH}$. Based on high-mass accuracy, spectral data, and previous reports, tentative compound identifications were assigned. Our findings revealed that IC-MeOH inhibited the proliferation of HeLa and CaSki cells. The plant extract was also found to induce a concentration- and time-dependent apoptosis and cell cycle arrest in the G0/G1 phase (IC ${ }_{50}$ value) in CaSki cell line. Analysis of IC-MeOH permitted the identification of 10 compounds already reported for their anticancer activity, epicatechin, curcumin, (-)-yatein, caffeic acid, myricetin, jatrorrhizine, harmaline, cinnamaldehyde, dobutamine, and syringin. In conclusion, IC-MeOH is a rich source of cytotoxic metabolites that inhibits human cervical cancer proliferation via apoptosis and cell cycle arrest.

\section{Introduction}

Cervical cancer is the fourth most common cancer in women. In 2018, an estimate of 570000 women were diagnosed with cervical cancer worldwide and about 311000 died of the disease. Almost all cervical cancer cases (99\%) are caused by high-risk human papillomaviruses (HPV), an extremely common virus transmitted through sexual contact. Although most HPV infections are cured spontaneously with no symptoms, persistent infection can cause cervical cancer in women. Cervical cancer is one of the most successfully curable forms of cancer when diagnosed [1]. The chemodrugs used to treat cervical cancer include cisplatin, carboplatin, oxaliplatin, paclitaxel, and topotecan. Nonethe- less, cervical cancer cells may develop resistance to cisplatin, main chemotherapy drug used for patients suffering from the cervical cancer. This substantially compromises the efficacy of cisplatin in the treatment of advanced or recurrent cervical cancer [2]. Given the fact that cisplatin can damage the kidney (nephrotoxicity) and display other common side effects such as anaphylaxis, leukopenia, neutropenia, thrombocytopenia, anaemia, hepatotoxicity, and cardiotoxicity [3], natural bioactive compounds may offer a better solution. Drug development using natural products has been extensively explored by researchers [4], and the use of plantderived molecules is frequent in cancer research. The plant kingdom is made up of around 250000 species [5], which are regularly exposed to stressful conditions due to biotic 
and abiotic factors in their living environment [6]. To survive under such difficult and stressful conditions, plants undergo some important modifications leading to the synthetic stimulation of secondary metabolites, which are known for their various pharmacological activities [7]. The in vitro investigations of Kuete et al. [8,9], and Nayim et al. [10] have shown the cytotoxic effects of the methanolic root extract of $I$. cylindrica against a panel of cancer cell lines including leukemia cells (CCRF-CEM and HL-60), breast cancer cells (MDA-MB-231-bcrp Clone 23), human wildtype HCT116 $\left(\mathrm{P}^{53+/+}\right)$ colon cancer cells, and pancreatic cancer cells Mia PaCa-2. The in vitro study conducted by Keshava et al. [11] had revealed the weak cytotoxic effect of the methanol leaf extract of $I$. cylindrica against the human oral squamous carcinoma cell line SCC-9, and from investigations of Kwok et al. [12], the ethyl acetate extract of I. cylindrica leaf showed an antiproliferative activity against colorectal cancer cells HT-29. Plants' biological activities rely on their phytochemical composition, and chromatography coupled to mass spectrometry is the most widely applied technology used for the analysis of samples in very complex matrices such as plant extracts [13]. To the best of our knowledge, no research work has highlighted the anticancer mode of action of the methanolic extract of Imperata cylindrica root against cervical cancer. Thus, this study aimed at evaluating the metabolic profile of IC-MeOH using an ultrahigh-performance liquid chromatography-highresolution mass spectrometry, and its anticancer mode of action toward human cervical cancer cells.

\section{Materials and Methods}

2.1. Collection of Plant Material. Roots of I. cylindrica (Gramineae) were collected in June 2019, from the "Menoua" Division in the West Region. The collected plant was identified by Mr. Nana Victor of the National Herbarium of Cameroon (Yaounde) under the voucher number 30139/SRF-Cam.

2.2. Extraction of Plant Material. The dried roots of I. cylindrica $(100 \mathrm{~g})$ were ground and macerated in methanol $(500 \mathrm{~mL})$ at room temperature for two (02) days. During extraction, the sample was shaken repeatedly. The obtained solution was filtered using Whatman No. 1 paper. Subsequently, the solvent was recovered in a rotary evaporator (BÜCHI R-Rotavapor model R-2000) and the resulting product was dried and lyophilized (Labconco Freeze Dryer $-105^{\circ} \mathrm{C}$, ThermoFisher, USA). The extraction yield was $7 \%$.

2.3. Ultrahigh-Performance Liquid Chromatography-HighResolution Mass Spectrometry. The ultrahigh-performance liquid chromatography-high-resolution mass spectrometry (UHPLC-HRMS) analysis was used to assess the chemical profile of IC-MeOH [14]. Seventy-five (75) mg of IC$\mathrm{MeOH}$ was weighed, and $1 \mathrm{~mL}$ of $100 \%$ methanol was added and vortexed well. The sample was sonicated and centrifuged at $14800 \mathrm{rpm}$ at $4^{\circ} \mathrm{C}$ for $10 \mathrm{~min}$. The obtained supernatants were spiked with reserpine (positive ion mode) and
Taurocholate-D8 (negative ion mode) for reverse phase and hydrophilic interaction liquid chromatography (HILIC) analyses. Afterward, the samples were vortexed and centrifuged at $14500 \mathrm{rpm}$ at $4^{\circ} \mathrm{C}$ for $10 \mathrm{~min}$. Ten (10) $\mu \mathrm{L}$ of the supernatant was injected into the UHPLC-HRMS system. The mass spectrometer employed for UHPLC-HRMS analysis was a Q-Exactive Orbitrap (ThermoFisher Scientific, San Jose, CA, USA) equipped with a heated electrospray ionisation (HESI) source. It also houses a HCD (higher-energy collision dissociation) cell for carrying out MSn experiments. The Q-Exactive Orbitrap was coupled to a Dionex UltiMate 3000 UHPLC system (ThermoFisher Scientific, San Jose, CA, USA). This system was provided with a column oven (set at $40^{\circ} \mathrm{C}$ ), an autosampler, and a thermocontroller (set at $4^{\circ} \mathrm{C}$ ). Separation of the $\mathrm{IC}-\mathrm{MeOH}$ was done using a $\mathrm{C} 18$ column $(150 \mathrm{~mm} \times 4.6 .1 \mathrm{~mm}, 5 \mu \mathrm{m})$ (Phenomenex Luna, India Pvt. Ltd.) and HILIC column $(150 \mathrm{~mm} \times 4.6 \mathrm{~mm}$, $5 \mu \mathrm{m}$ ) (Phenomenex Luna, India Pvt. Ltd.) at $40^{\circ} \mathrm{C}$. Experiments were performed with sample analysis in reversephase chromatography (positive and negative) and HILIC (positive and negative) modes. The MS operating conditions for all three experimental replicate analyses were as follows: spray voltage, $+2500 \mathrm{~V}(-2500 \mathrm{~V}$ for negative mode); capillary temperature, $280^{\circ} \mathrm{C}$; vaporizer temperature, $320^{\circ} \mathrm{C}$; sheath gas, 30 arbitrary units (40 for negative mode); and auxiliary gas, 10 arbitrary units. Injector settings were as follows: 0-2 mins: waste, 2-45 mins: load, and 45-55 mins: waste. The UHPLC-HRMS instrumentation method was used for the HILIC phase, and the UHPLC-HRMS instrumentation method for the reverse phase is compiled in Tables S1 and S2. After mass analysis, the tentative identification of compounds was achieved based on the matching of accurate $\mathrm{m} / \mathrm{z}$ with local library of authentic standards from PlantCyc $(10 \mathrm{ppm})$ database, METLIN Mass Spectral Database (accurate mass and/or MS/MS library), and the literature data.

2.4. Human Cervical Cell Line Culture. The human cervical cancer cell lines HeLa and CaSki purchased from American Type Culture Collection (ATCC, Rockville, MD, USA) were maintained in Dulbecco's Modified Eagle Medium (Gibco, ThermoFisher, USA) supplemented with 10\% Foetal Bovine Serum (Gibco, ThermoFisher, USA) and 1\% penicillin and streptomycin $(10 \mathrm{~mL} / \mathrm{L})$ (Gibco, ThermoFisher, USA). The nontumor human cervical cell line HCK1T (donated by the National Cancer Center Research Institute (NCCRI), Japan) was maintained in 3:1 $(v / v)$ Nutrient MixtureDulbecco's Modified Eagle Medium supplemented with $5 \%$ FBS, $0.4 \mu \mathrm{g} / \mathrm{mL}$ hydrocortisone, $5 \mu \mathrm{g} / \mathrm{mL}$ insulin, $8.4 \mathrm{ng} / \mathrm{mL}$ toxin cholera, $10 \mathrm{ng} / \mathrm{mL}$ epidermal growth factor, $24 \mathrm{ng} / \mathrm{mL}$ adenine, and $5 \mu \mathrm{mol} / \mathrm{mL} \mathrm{Y-27632.} \mathrm{All} \mathrm{cells} \mathrm{were}$ incubated in a humidified atmosphere of $5 \% \mathrm{CO}_{2}$ at $37^{\circ} \mathrm{C}$. All experiments were performed with cells in the logarithmic growth phase.

2.5. Cell Viability Assay. The cell viability assay of IC-MeOH against HeLa, CaSki, and HCK1T cell lines was performed using the cell proliferation reagent WST-1 (Sigma-Aldrich, Roche Diagnostics, Germany) [15]. The stable tetrazolium 
salt WST-1 was cleaved to a soluble formazan by a complex cellular mechanism that occurs primarily at the cell surface. This bioreduction is a largely dependent dye formed directly on the glycolytic production of $\mathrm{NAD}(\mathrm{P}) \mathrm{H}$ in viable cells. Therefore, the amount of formazan dye formed directly correlates to the number of metabolically active cells in the culture. Briefly, cells were detached by treatment with $0.5 \%$ trypsin/EDTA (Gibco, Canada) and seeded at a density of $5.10^{3}$ cells $/ \mathrm{mL}$ and $6.10^{3}$ cells/well of a 96-well cell culture plate (Greiner, Bio-One, CELLSTAR, Germany), respectively, for HeLa and CaSki in a total volume of $100 \mu \mathrm{L}$; cells were allowed to attach overnight. Afterward, they were immediately treated with different concentrations of crude extract ranging from 3 to $384 \mu \mathrm{g} / \mathrm{mL}$ dissolved in $0.1 \%$ dimethyl-sulfoxide (Sigma-Aldrich) and incubated for 24, 48, and $72 \mathrm{~h}$; cisplatin (Celon Laboratories, India) was used as a positive control and tested from 0.1 to $100 \mu \mathrm{g} / \mathrm{mL}$. After the treatment periods, $10 \mu \mathrm{L}$ of WST- 1 reagent was added to each well and incubated for $1 \mathrm{~h}$. Absorbance was measured at $450 \mathrm{~nm}$ wavelength (Spectra-Max M5 Multimode reader). Each assay was performed at least three times, and the cell viability was evaluated with respect to untreated cells. IC50 values (concentration of the tested compounds required to reduce cell density to 50\%) were calculated by concentration-response curve fitting using GraphPad Prism version 8.1.0.

2.6. Clonogenic Assay. Colony formation assay was performed to assess the effect of IC-MeOH on CaSki cell line's clonogenic ability. The following protocol has been modified from a published version [16]. Briefly, cells were harvested by trypsinization from 70 to $80 \%$ confluent monolayer cell culture, washed with PBS, and resuspended in DMEM containing 10\% FBS. Afterward, cells were seeded in 6-well plates (Greiner, Bio-One, CELLSTAR, Germany) at a density of 1000 cells/well and incubated at $37^{\circ} \mathrm{C}$ in a humidified incubator. After $24 \mathrm{~h}$, the medium was replaced with fresh medium and cells were treated with different concentrations of the plant extract $(10,15,20,25$, and $30 \mu \mathrm{g} / \mathrm{mL})$ and $0.1 \%$ DMSO vehicle for $24 \mathrm{~h}$. The medium was then replaced with fresh DMEM containing 10\% FBS. The cells were allowed to grow for an additional 11 days. After this period, the media were removed and cells were washed with PBS, fixed with acetic acid-methanol $(1: 7 v / v)$, and incubated for 5 to $10 \mathrm{~min}$ at room temperature (RT). Afterward, colonies of cells were stained with $0.5 \%$ crystal violet (Sigma-Aldrich) and incubated for $2 \mathrm{~h}$ at room temperature. Cristal violet was discarded, cells were washed in tap water and dried overnight, and plates were imaged. The colonies containing at least 50 cells were counted under a Nikon inverted microscope Eclipse TE2000-S. The data were collected from three independent experiments performed in triplicate.

2.7. Apoptosis Analysis. A quantitative assessment of apoptosis was performed using phycoerythrin (PE) Annexin V Apoptosis Detection Kit I (BD Biosciences, Pharmagen, USA) [17]. CaSki cells were seeded in 6-well plates at a density of $4 \times 10^{5}$ cells/well for $24 \mathrm{~h}$, then treated with $0.1 \%$ DMSO or $0.3 \%$ saline, either with IC-MeOH $\left(1 / 2 \mathrm{IC}_{50}\right.$,
$\mathrm{IC}_{50}$, and $2 \mathrm{IC}_{50}$ ) or with cisplatin used as a positive control $\left(1 / 2 \mathrm{IC}_{50}, \mathrm{IC}_{50}\right.$, and $\left.2 \mathrm{IC}_{50}\right)$ for 24 and $48 \mathrm{~h}$. After the different treatment days, cells were taken out, washed twice with PBS, trypsinized, centrifuged for pellet collection, and resuspended in cold PBS and later in $1 \times$ binding buffer $\left(1 \times 10^{6}\right.$ cells $/ \mathrm{mL}$ ). Afterward, $100 \mu \mathrm{L}$ of cell resuspension solution was transferred in $1.5 \mathrm{~mL}$ Eppendorf; $5 \mu \mathrm{L}$ of phycoerythrin-conjugated annexin $\mathrm{V}$ (annexin V-PE) and $5 \mu \mathrm{L}$ of 7 -Amino Actinomycin D (7-AAD) were added and followed by 15 min incubation in the dark at room temperature. The stained cells were then diluted with $1 \times$ binding buffer and immediately analyzed using a flow cytometer (Becton Dickinson FACSVerse). Data from 10.000 events were collected per data file. In four zones of the drawn quadrant, we had viable cells (Q1), cells bound to annexin V-PE only (early apoptotic cells, Q2), and cells bound both to annexin-PE and 7-AAD (late apoptotic cells, Q3).

2.8. Cell Cycle Analysis. The effect of the methanolic root extract of I. cylindrica on CaSki cell cycle was determined by flow cytometry-based fluorescence-activated cell sorting (FACS) analysis of propidium iodide- (PI-) stained cells [18]. Cells were seeded in 6-well plates at a density of 1.5 $\times 10^{5}$ cells/well and incubated overnight. After serum starvation for $24 \mathrm{~h}$, they were treated with either $0.1 \%$ DMSO (negative controls) or IC-MeOH $\left(1 / 2 \quad \mathrm{IC}_{50}, \mathrm{IC}_{50}\right.$, and 2 $\mathrm{IC}_{50}$ ) for 24 and $48 \mathrm{~h}$. After the different treatment days, cells were trypsinized, washed with cold phosphate-buffered saline (PBS), fixed in ice-cold 70\% ethanol overnight, and redissolved in $1 \mathrm{~mL}$ of PBS solution supplemented with RNase and stained with PI. After 15 min of incubation at $37^{\circ} \mathrm{C}$, analysis was done using flow cytometry (Becton Dickinson FACSVerse). FlowJo software was used to process the data.

2.9. Statistical Analysis. Each experiment was performed three times, on independent cell passages. Statistical analysis was performed using GraphPad Prism version 8.1.0. The data are plotted as the mean $\pm \mathrm{SD}$. Differences between the means of treated and untreated samples were evaluated using one-way analysis of variance (one-way ANOVA) followed by post hoc Dunnett's multiple comparison test. $p$ values $<0.05$ were considered to be statistically significant, and significance was marked as* $p$ values $<0.05,{ }^{* *} p$ values $<0.01,{ }^{* * *} p$ values $<0.001$, and ${ }^{* * * *} p<0.0001$.

\section{Results}

3.1. The Methanol Extract of Imperata cylindrica Root Cytotoxicity toward Cervical Cancer Cells. The antiproliferative activity of IC-MeOH on the human cervical cancer cell lines HeLa and CaSki was evaluated using the watersoluble tetrazolium-1 reagent (WST-1). Multiple concentrations of $\mathrm{IC}-\mathrm{MeOH}$ and cisplatin were used, and $\mathrm{IC}_{50}$ values were determined from the dose-response curve. The cytotoxicity results of both $\mathrm{IC}-\mathrm{MeOH}$ and the positive control against the abovementioned cell lines are shown in Figure 1 and Table 1. IC-MeOH showed a concentrationand time-dependent growth inhibition, with $\mathrm{IC}_{50}$ values 

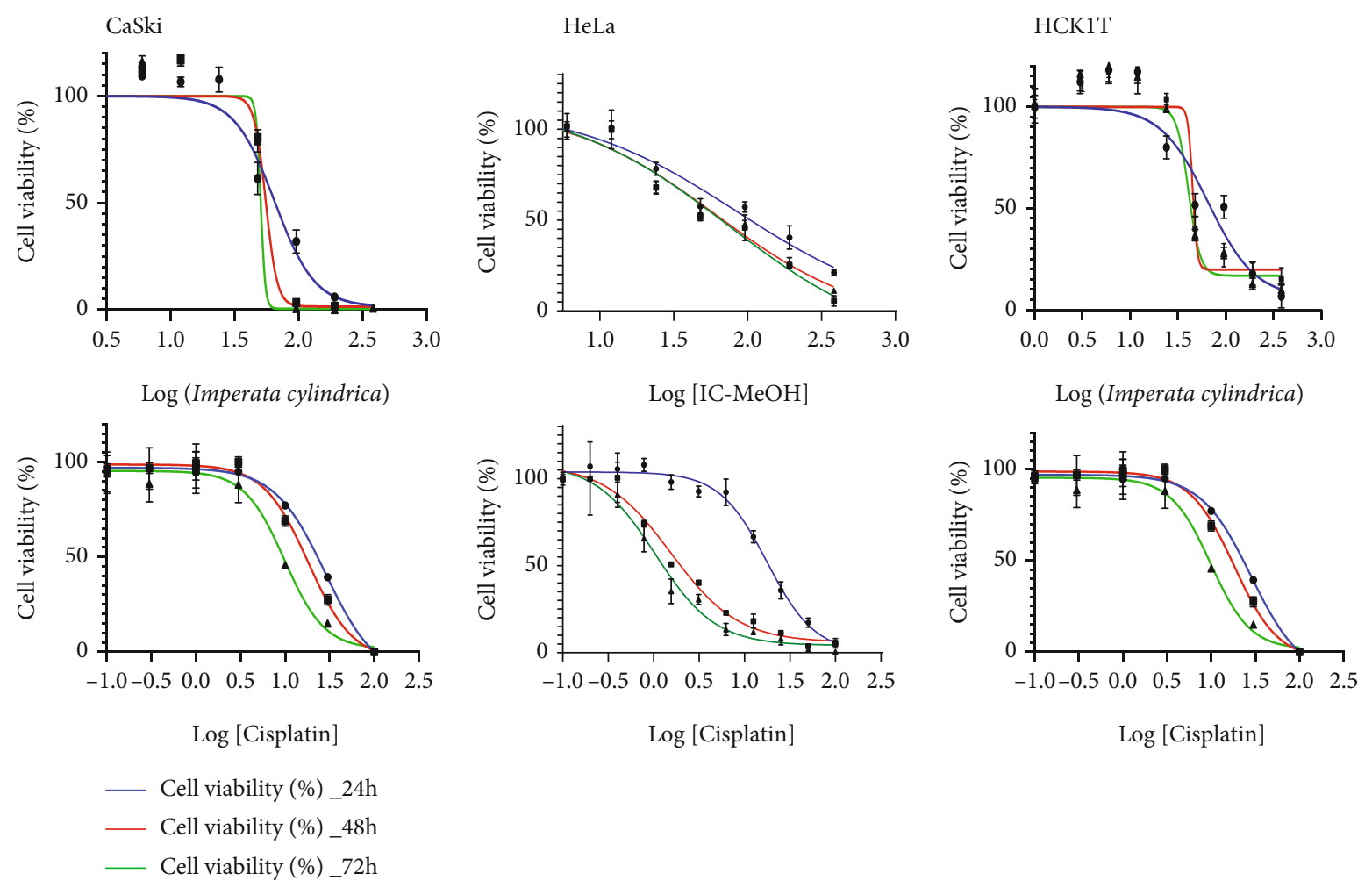

Figure 1: The dose-response curves of IC-MeOH and cisplatin. IC-MeOH: Imperata cylindrica root's methanol extract.

TABLE 1: $\mathrm{IC}_{50}$ concentrations $(\mu \mathrm{g} / \mathrm{mL})$ of cylindrica root methanol extract and cisplatin.

\begin{tabular}{lcccccccccc}
\hline $\begin{array}{l}\text { Cell line } \\
\begin{array}{l}\text { Treatment } \\
\text { time }\end{array}\end{array}$ & $24 \mathrm{~h}$ & $48 \mathrm{~h}$ & $72 \mathrm{~h}$ & $24 \mathrm{~h}$ & $48 \mathrm{~h}$ & $72 \mathrm{~h}$ & $24 \mathrm{~h}$ & $48 \mathrm{~h}$ & $72 \mathrm{~h}$ \\
\hline IC-MeOH & $84.17 \pm 4.00$ & $75.05 \pm 3.42$ & $68.00 \pm 2.39$ & $65.14 \pm 3.35$ & $55.52 \pm 0.82$ & $50.71 \pm 1.53$ & $65.54 \pm 2.10$ & $45.19 \pm 1.70$ & $40.91 \pm 2.00$ \\
Cisplatin & $17.63 \pm 1.20$ & $1.6375 \pm 0.09$ & $0.9347 \pm 0.08$ & $26.29 \pm 1.70$ & $12.07 \pm 1.00$ & $6.40 \pm 0.37$ & $28.23 \pm 1.41$ & $18.15 \pm 1.01$ & $9.83 \pm 0.70$ \\
\hline
\end{tabular}

$\mathrm{IC}_{50}$ : inhibitory concentration 50; IC-MeOH: Imperata cylindrica root's methanol extract.

$(\mu \mathrm{g} / \mathrm{mL})$ of $84.17 \pm 4.00,75.05 \pm 3.42$, and $68.00 \pm 2.39$ for HeLa and $65.14 \pm 3.35,55.52 \pm 0.81$, and $50.51 \pm 1.53$ for CaSki, respectively, after 24,48 , and $72 \mathrm{~h}$ of treatment periods. Cisplatin also impaired HeLa and CaSki cell growth in a concentration- and time-dependent manner. However, IC-MeOH showed the best $\mathrm{IC}_{50}$ values with CaSki compared to HeLa. On the nontumor cervical cell line HCK1T, both IC- $\mathrm{MeOH}$ and cisplatin displayed a concentration- and time-dependent cytotoxicity, as their $\mathrm{IC}_{50}$ values on this cell line were in a decreasing order with increasing incubation periods.

3.2. Effect of I. cylindrica Root Extract on CaSki Cell Line's Clonogenic Ability. Clonogenic assay is the method of choice to determine cell reproductive death after treatment with ionising radiation but can also be used to determine the effectiveness of other cytotoxic agents. This method was used in our study to test whether IC-MeOH can reduce the clonogenic survival of CaSki cells after $24 \mathrm{~h}$ of treatment with different concentrations. From the obtained results dis- played in Figure 2, it was notable that IC-MeOH significantly inhibited the ability of CaSki cells to form colonies at concentrations of $10,15,20,25$, and $30 \mu \mathrm{g} / \mathrm{mL}$ compared to the control (untreated cells). Moreover, the anticlonogenic effect of IC-MeOH was concentration-dependent as shown by the diagram in Figure 2.

3.3. I. cylindrica Root Extract Induces Apoptosis in CaSki Cells. 7-AAD-annexin-V double staining has been used to differentiate healthy CaSki cells from early and late apoptotic CaSki cells (Figure 3(a)). Fluorescence-activated cell sorting analysis of the untreated (control) and treated cells revealed that $\mathrm{IC}-\mathrm{MeOH}\left(\mathrm{IC}_{50}\right.$ and $\left.2 \mathrm{IC}_{50}\right)$ as well as cisplatin $(1 / 2$ $\mathrm{IC}_{50}, \mathrm{IC}_{50}$, and $2 \mathrm{IC}_{50}$ ) significantly induced apoptosis in CaSki cells after $24 \mathrm{~h}$ and $48 \mathrm{~h}$ of treatment. The percentages of apoptotic cells induced by $\mathrm{IC}-\mathrm{MeOH}$ and cisplatin are shown in Figure 3(b).

3.4. I. cylindrica Root Extract Arrests CaSki's Cell Cycle at the $G_{0} / G_{1}$ Phase. CaSki cell cycle distribution was studied in the 

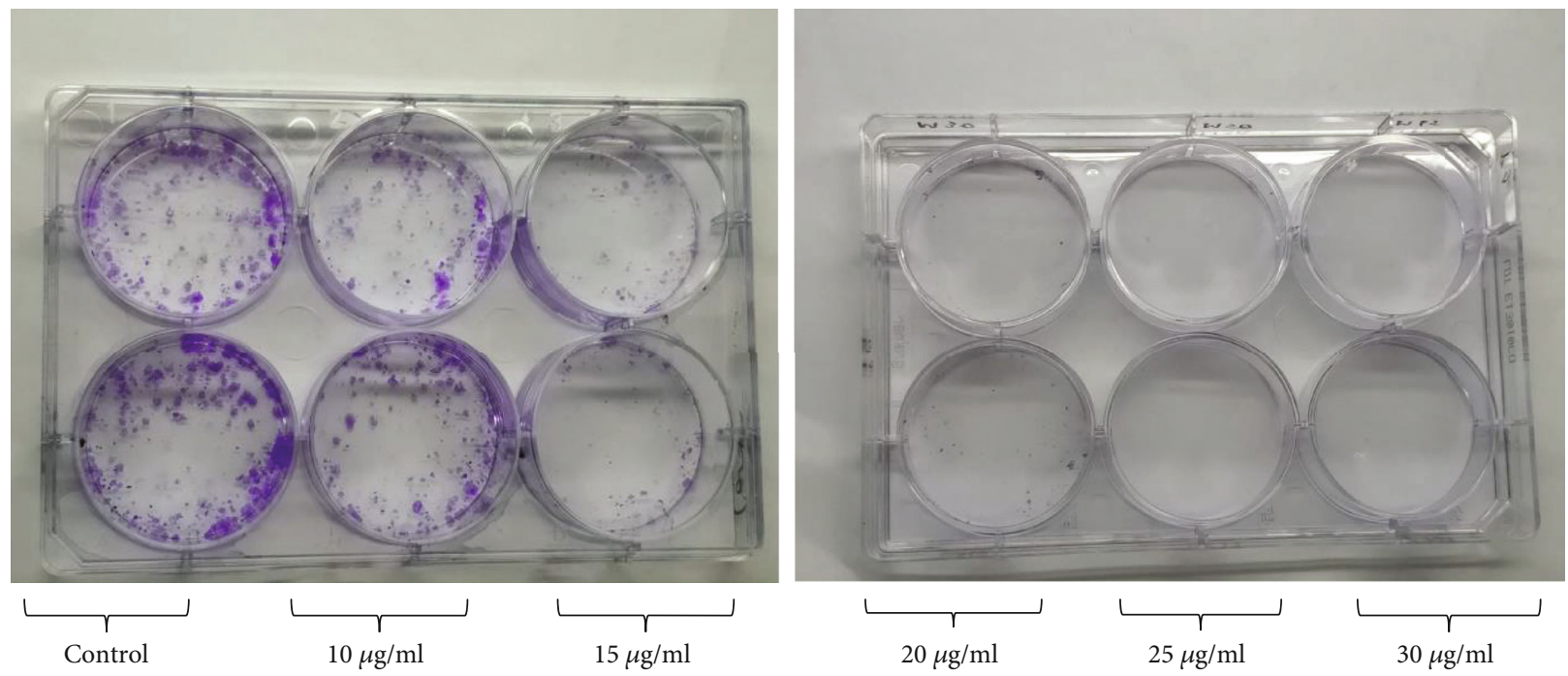

(a)

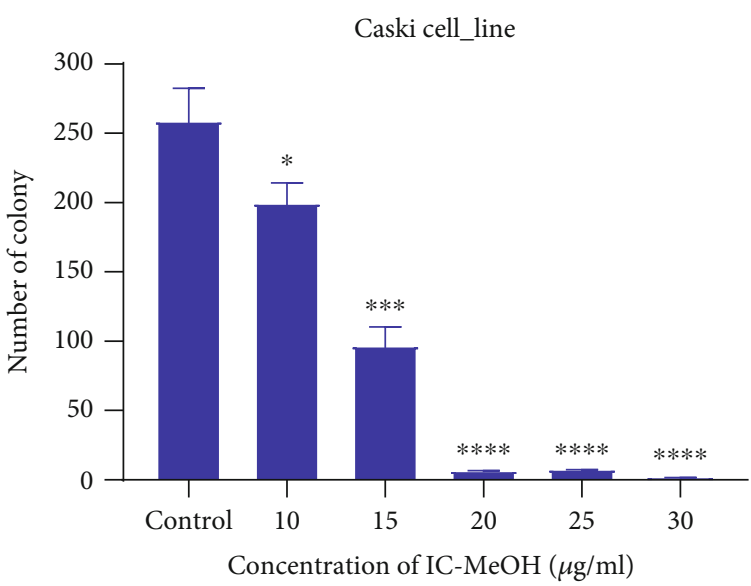

(b)

Figure 2: Anticlonogenic effect of IC-MeOH against CaSki cells: (a) clonogenic ability of CaSki cells in the absence (control) and in the presence of different concentrations of IC-MeOH; (b) number of colonies formed by CaSki cells in the absence (control) and in the presence of IC-MeOH and after 24 hours of treatment. All data are presented as the mean \pm SD and are representative of three independent experiments. $p$ values $<0.05$ were considered to be statistically significant and significant, marked as ${ }^{*} p$ values $<0.05$ vs. control, ${ }^{* *} p$ values vs. control $<0.01,{ }^{* * *} p$ values vs. control $<0.001$, and ${ }^{* * * *} p<0.0001$ vs. control. IC-MeOH: Imperata cylindrica root's methanol extract.

absence and in the presence of IC- $\mathrm{MeOH}$ at different concentrations equivalent to $1 / 2 \mathrm{IC}_{50}, \mathrm{IC}_{50}$, and $2 \mathrm{IC}_{50}$. Compared to untreated cells, at all treatment periods, the percentage of cells was increased at the G0/G1 phase and decreased at the $\mathrm{S}$ and $\mathrm{G} 2 / \mathrm{M}$ phases in the group of cells treated at $1 / 2 \mathrm{IC}_{50}$ and $\mathrm{IC}_{50}$. However, as shown in Figures 4(a) and 4(b), the aforementioned changes in cell's population percentage were significant at $\mathrm{IC}_{50}$ but not at $1 / 2 \mathrm{IC}_{50}$. The same observation was made for the group cells treated at $2 \mathrm{IC}_{50}$, except a significant decrease of cells at the G0/G1 phase and a large number of dead cells in the sub-G1 phase.

3.5. UHPLC-HRMS Analysis of I. cylindrica Root Methanol Extract. A study was conducted on the IC-MeOH based on UHPLC-HRMS in the negative and positive ion mode to identify the potential bioactive chemicals that may be responsible for its recorded anticancer activity. The chromatogram of the UHPLC-HRMS analysis of IC- $\mathrm{MeOH}$ is shown in Figure 5. The analysis led to the identification of 46 compounds with high-resolution mass spectrometry and MS/MS data (Table 2).

A total of nine compounds already reported for their anticancer activity have been tentatively identified in IC$\mathrm{MeOH}$, including 05 flavonoids (epicatechin (1), curcumin (2), (-)-yatein (3), caffeic acid (4) and myricetin (5)), 02 alkaloids (jatrorrhizine (6) and harmaline (7)), 01 phenylpropanoid (cinnamaldehyde (8)), 01 synthetic catecholamine (dobutamine (9)), and 01 monosaccharide derivative that is trans-sinapyl alcohol attached to a $\beta$-D-glucopyranosyl residue at position 1 via a glycosidic linkage (syringin (10)). The chemical structures of the compounds are shown in Figure 6. 

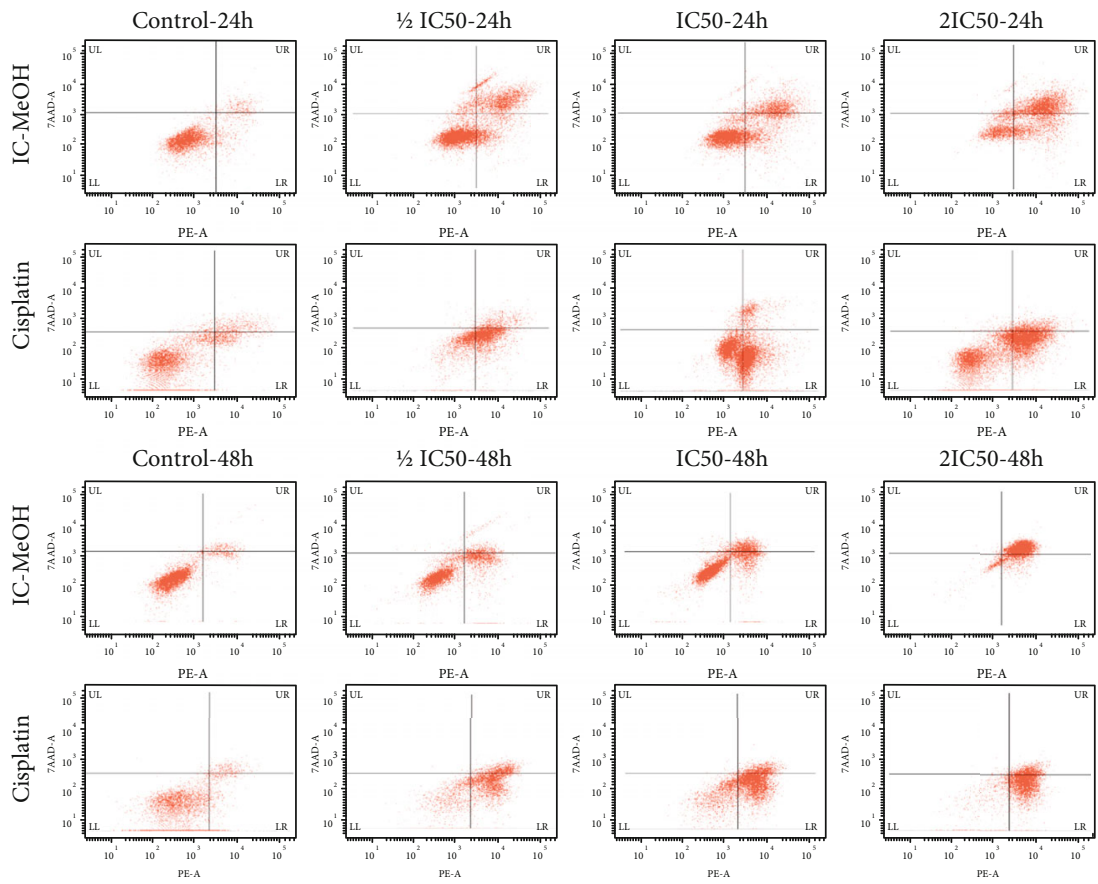

(a)
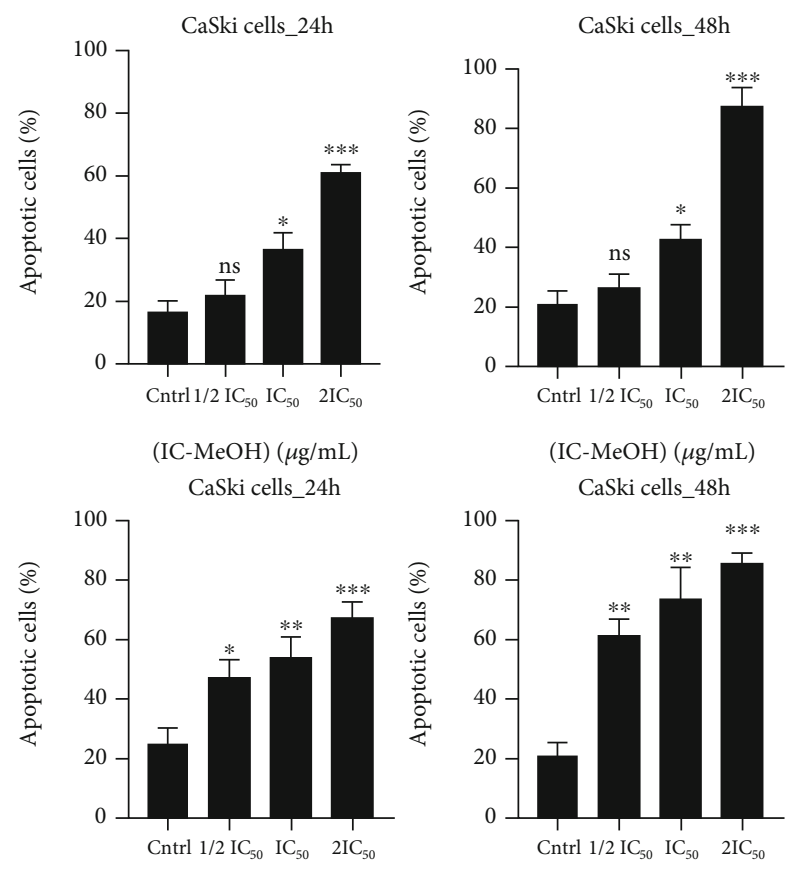

(Cisplatin) $(\mu \mathrm{g} / \mathrm{mL})$

(Cisplatin) $(\mu \mathrm{g} / \mathrm{mL})$

(b)

Figure 3: (a) Apoptotic effect of IC-MeOH in CaSki cells. Untreated CaSki cells (control) and treated CaSki cell population with IC-MeOH or cisplatin $\left(1 / 2 \mathrm{IC}_{50}, \mathrm{IC}_{50}\right.$, and $\left.2 \mathrm{IC}_{50}\right)$ at different stages of apoptosis after $24 \mathrm{~h}$ and $48 \mathrm{~h}$. Data from 10.000 cells had been collected per data file; in four zones of the drawn quadrant, we had viable cells (Q1), cells bounded to annexin V-PE only (Q2: early apoptotic cells), and cells bounded to both annexin V-PE and 7-AAD (Q3: late apoptotic cells). IC-MeOH: Imperata cylindrica root's methanol extract; $\mathrm{IC}_{50}$ : inhibitory concentration 50 of IC-MeOH; $1 \frac{1}{2} \mathrm{IC}_{50}$ : half of the inhibitory concentration 50 of IC-MeOH; $2 \mathrm{IC}_{50}$ : two times the inhibitory concentration 50 of IC-MeOH; $24 \mathrm{~h}, 48 \mathrm{~h}$, and $72 \mathrm{~h}$ : treatments' times. (b) Percentage of apoptotic cells (early and late) in the control (untreated CaSki cells) and treated CaSki cells. All data presented are the mean \pm SD and are representative of three independent experiments. $p$ values $<0.05$ were considered to be statistically significant, and significance was marked as ${ }^{*} p$ values $<0.05$, ${ }^{* *} p$ values $<$ 0.01 , and ${ }^{* * *} p$ values < 0.001 . IC-MeOH: Imperata cylindrica root's methanol extract; Cntrl: control; $\mathrm{IC}_{50}$ : inhibitory concentration 50 of IC-MeOH; 1/2 IC I0 $_{5}$ half of the inhibitory concentration 50 of IC-MeOH; $2 \mathrm{IC}_{50}$ : two times the inhibitory concentration 50 of IC$\mathrm{MeOH}$; CaSki_24 h: CaSki cells treated during $24 \mathrm{~h}$; CaSki_48 h: CaSki cells treated during $48 \mathrm{~h}$. 


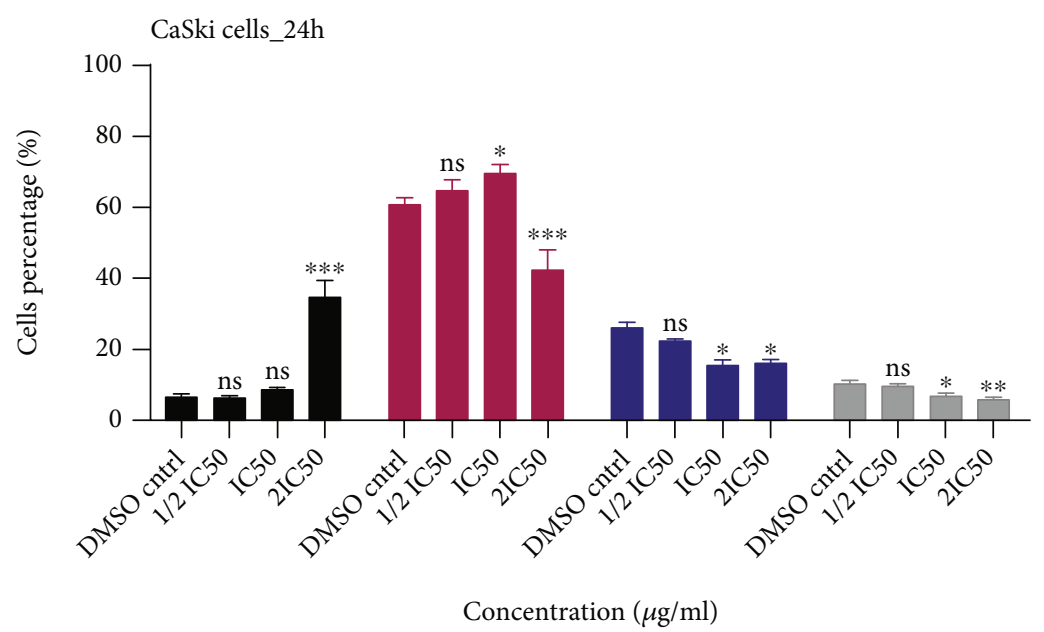

(a)

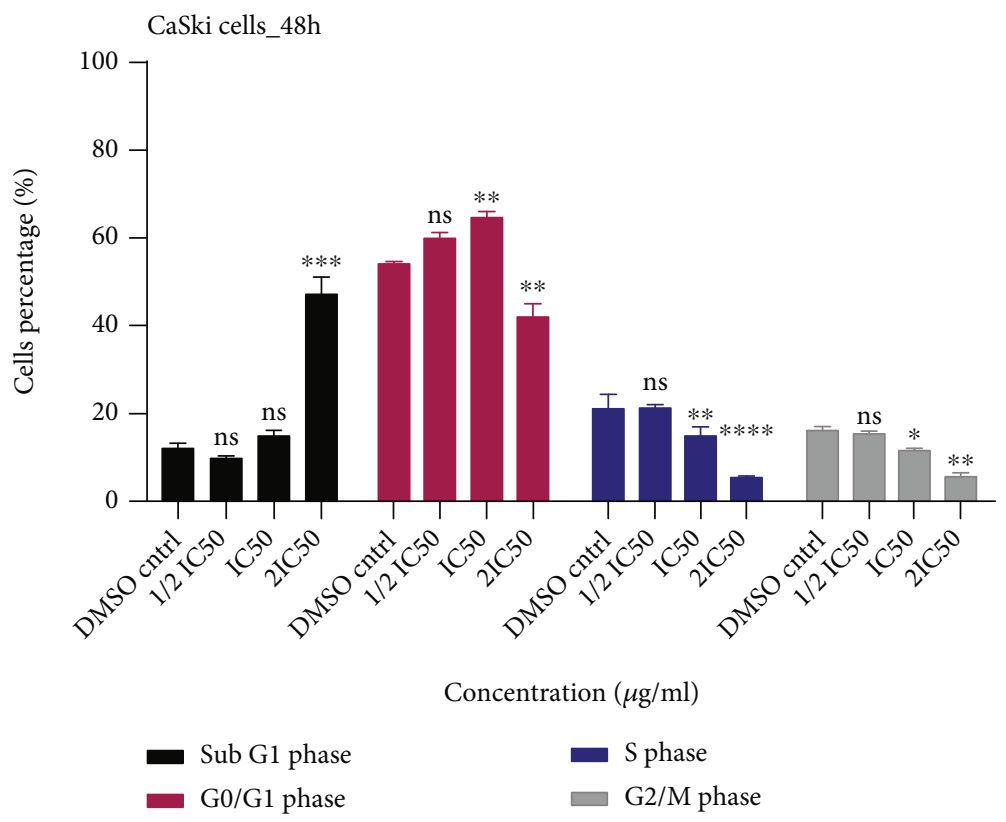

(b)

Figure 4: Effect of IC-MeOH on CaSki cell cycle after $24 \mathrm{~h}$ (a) and $48 \mathrm{~h}$ of treatment (b). IC-MeOH: Imperata cylindrica root's methanol extract; DMSO Cntrl: control (untreated cells); $\mathrm{IC}_{50}$ : inhibitory concentration 50 of IC-MeOH; 1/2 $\mathrm{IC}_{50}$ : half of the inhibitory concentration 50 of IC-MeOH; 2 IC $_{50}$ : two times the inhibitory concentration 50 of IC-MeOH; CaSki_24h: CaSki cells treated during $24 \mathrm{~h}$; CaSki_48 h: CaSki cells treated during $48 \mathrm{~h}$.

\section{Discussion}

The present study was designed to identify the anticancer chemicals of IC-MeOH and to assess the inhibitory potential of the latter against human cervical cancer cell lines and the mode (s) of action (s). The UHPLC-HRMS analysis used for the metabolite profiling of $\mathrm{IC}-\mathrm{MeOH}$ indicated the presence of several compounds already reported for their anticancer effects, belonging in majority to alkaloids and phenolic compounds groups. Naturally derived phenolic compounds and alkaloids are known to exhibit potent anticancer activities as well as combat various diseases through specific modes of actions. Among the identified active ingredients of IC$\mathrm{MeOH}$, epicatechin, curcumin, and myricetin are cytotoxic agents causing cancer cell death through induced apoptosis and cell cycle arrest [19-24]. Yatein is known to induce cell cycle arrest and microtubule destabilisation in human lung adenocarcinoma cells [25], and caffeic acid initiates cancer cell death by increasing intracellular ROS, altering mitochondrial membrane potential, lipid peroxidation, and apoptosis in HeLa and ME-180 cervical carcinoma cell lines [26]. Jatrorrhizine inhibits growth and induces C8161 metastatic melanoma cell cycle arrest at G0/G1 transition [27]. Harmaline induces apoptosis and prevents the proliferation and migration of human breast cancer cell lines [28]. Dobutamine displays antitumor activity against human osteosarcoma cells, via cell apoptosis and cell cycle arrest in the G2/M phase [29]. Cinnamaldehyde promotes apoptosis by 

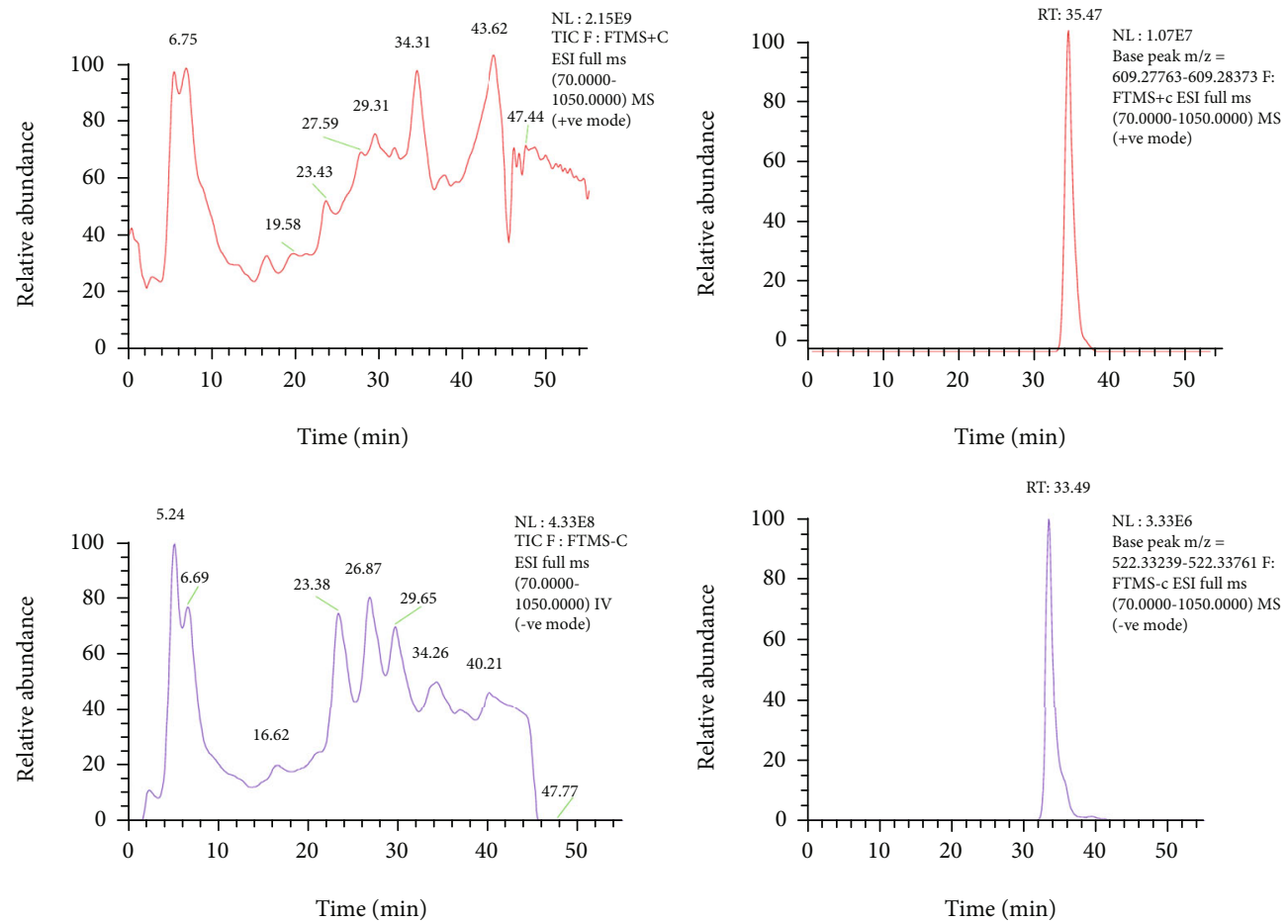

(a)
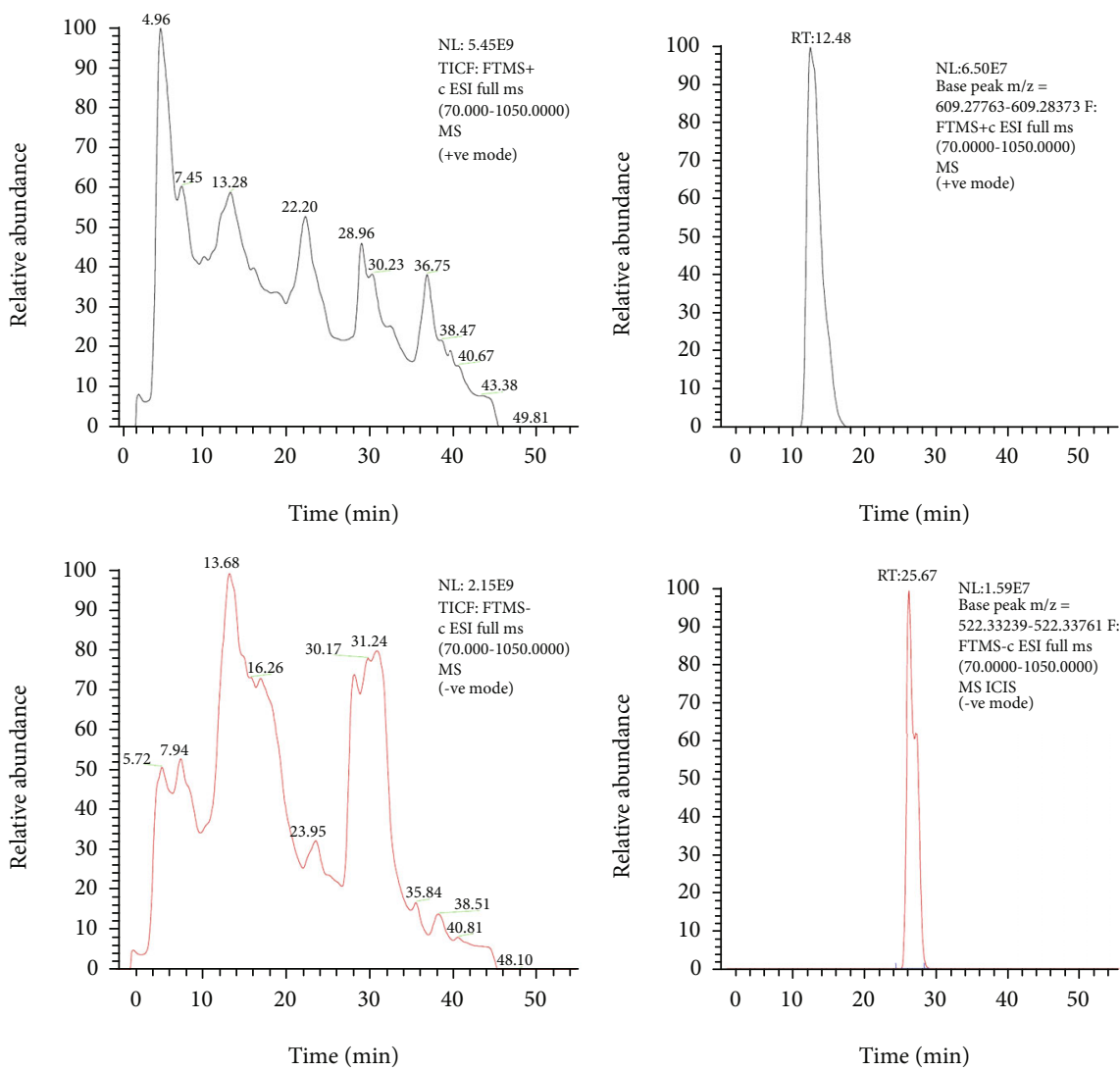

(b)

FIgURE 5: (a) UHPLC-HRMS chromatogram of IC-MeOH in the reverse phase, negative and positive ion mode. IC-MeOH: Imperata cylindrica root's methanol extract. (b) UHPLC-HRMS chromatogram of IC-MeOH in the HILIC phase, negative and positive ion mode. IC-MeOH: Imperata cylindrica root's methanol extract. 
TABLE 2: Tentative identified compounds from methanol extract of I. cylindrica root.

\begin{tabular}{|c|c|c|c|c|c|c|}
\hline No. & MW & $\begin{array}{c}{[\mathrm{M}-\mathrm{H}]^{-}} \\
(m / z)\end{array}$ & $\begin{array}{c}\mathrm{RT} \\
(\mathrm{min})\end{array}$ & MF & Tentatively identified compounds & References \\
\hline 1 & 125.014 & 124.0212 & 4.077 & $\mathrm{C}_{2} \mathrm{H}_{7} \mathrm{NO}_{3} \mathrm{~S}$ & Taurine & \\
\hline 2 & 273.966 & 272.9591 & 4.09 & $\mathrm{C}_{5} \mathrm{H}_{11} \mathrm{AsO}_{8}$ & Ribose-1-arsenate & \\
\hline 3 & 155.034 & 154.0424 & 4.885 & $\mathrm{C}_{3} \mathrm{H}_{10} \mathrm{NO}_{4} \mathrm{P}$ & N-Methylethanolamine phosphate & \\
\hline 4 & 256.079 & 255.0724 & 4.931 & $\mathrm{C}_{11} \mathrm{H}_{13} \mathrm{NO}_{6}$ & $\beta$-D-Ribosylnicotinate & \\
\hline 5 & 198.052 & 197.0596 & 6.192 & $\mathrm{C}_{9} \mathrm{H}_{10} \mathrm{O}_{5}$ & Vanillylmandelic acid (100) & \\
\hline 6 & 173.069 & 172.0766 & 7.833 & $\mathrm{C}_{7} \mathrm{H}_{11} \mathrm{NO}_{4}$ & N-Acetyl-L-glutamate 5 -semialdehyde & \\
\hline 7 & 314.155 & 313.1624 & 10.193 & $\mathrm{C}_{20} \mathrm{H}_{18} \mathrm{~N}_{4}$ & A bacteriochlorin & \\
\hline 8 & 153.042 & 152.0493 & 14.784 & $\mathrm{C}_{7} \mathrm{H}_{6} \mathrm{NO}_{3}$ & 3-Hydroxyanthranilate & \\
\hline 9 & 225.100 & 224.1079 & 15.732 & $\mathrm{C}_{12} \mathrm{H}_{11} \mathrm{~N}_{5}$ & Benzyladenine & \\
\hline 10 & 180.041 & 179.0345 & 20.723 & $\mathrm{C}_{9} \mathrm{H}_{8} \mathrm{O}_{4}$ & Caffeic acid & {$[41,42]$} \\
\hline 11 & 339.204 & 338.2110 & 22.805 & $\mathrm{C}_{18} \mathrm{H}_{28} \mathrm{NO}_{5}^{-}$ & (+)-7-Epi-12-hydroxyjasmonoyl-L-isoleucine & \\
\hline 12 & 214.110 & 213.1030 & 23.0 & $\mathrm{C}_{13} \mathrm{H}_{14} \mathrm{~N}_{2} \mathrm{O}$ & Harmaline & {$[41]$} \\
\hline 13 & 297.193 & 296.2012 & 23.445 & $\mathrm{C}_{16} \mathrm{H}_{27} \mathrm{NO}_{4}$ & $\mathrm{~N}$-(3-Oxododecanoyl) homoserine lactone & \\
\hline 14 & 164.057 & 163.0642 & 23.652 & $\mathrm{C}_{8} \mathrm{H}_{8} \mathrm{~N}_{2} \mathrm{O}_{2}$ & Ricinine & \\
\hline 15 & 289.167 & 288.1746 & 24.843 & $\mathrm{C}_{17} \mathrm{H}_{23} \mathrm{NO}_{3}$ & Atropine & \\
\hline 16 & 346.118 & 345.1108 & 24.921 & $\mathrm{C}_{17} \mathrm{H}_{18} \mathrm{~N}_{2} \mathrm{O}_{6}$ & Miraxanthin-V & \\
\hline 17 & 385.188 & 384.1959 & 25.209 & $\mathrm{C}_{22} \mathrm{H}_{27} \mathrm{NO}_{5}$ & O-Methylandrocymbine & \\
\hline 18 & 400.150 & 399.1572 & 25.220 & $\mathrm{C}_{22} \mathrm{H}_{24} \mathrm{O}_{7}$ & $(-)$-yatein & \\
\hline 19 & 354.165 & 353.1721 & 26.31 & $\mathrm{C}_{14} \mathrm{H}_{22} \mathrm{~N}_{6} \mathrm{O}_{5}$ & Ala-His-Gln & \\
\hline 20 & 306.144 & 305.1513 & 27.242 & $\mathrm{C}_{13} \mathrm{H}_{18} \mathrm{~N}_{6} \mathrm{O}_{3}$ & Lupinate & \\
\hline 21 & 380.145 & 379.1386 & 27.409 & $\mathrm{C}_{14} \mathrm{H}_{24} \mathrm{~N}_{2} \mathrm{O}_{10}$ & EGTA & \\
\hline 22 & 222.088 & 221.0962 & 27.561 & $\mathrm{C}_{12} \mathrm{H}_{14} \mathrm{O}_{4}$ & Coniferyl acetate & \\
\hline 23 & 144.057 & 143.0642 & 27.797 & $\mathrm{C}_{10} \mathrm{H}_{8} \mathrm{O}$ & 1-naphthol & \\
\hline 24 & 350.174 & 349.1814 & 28.264 & $\mathrm{C}_{19} \mathrm{H}_{25} \mathrm{O}_{6}^{-}$ & 16, 17-Dihydro-16 $\alpha, 17$-dihydroxy gibberellin A9 & \\
\hline 25 & 338.184 & 337.1918 & 28.549 & $\mathrm{C}_{17} \mathrm{H}_{26} \mathrm{~N}_{2} \mathrm{O}_{5}$ & A jasmonoyl-glutamine & \\
\hline 26 & 142.063 & 141.0709 & 28.713 & $\mathrm{C}_{7} \mathrm{H}_{10} \mathrm{O}_{3}$ & Homofuraneol & \\
\hline 27 & 301.167 & 300.1755 & 29.407 & $\mathrm{C}_{18} \mathrm{H}_{23} \mathrm{NO}_{3}$ & Dobutamine & \\
\hline 28 & 318.037 & 317.0301 & 29.442 & $\mathrm{C}_{15} \mathrm{H}_{10} \mathrm{O}_{8}$ & Myricetin & \\
\hline 29 & 284.125 & 283.1333 & 29.643 & $\mathrm{C}_{14} \mathrm{H}_{20} \mathrm{O}_{6}$ & 2-Phenylethyl $\beta$-D glucopyranoside & \\
\hline 30 & 379.246 & 378.2547 & 29.806 & $\mathrm{C}_{16} \mathrm{H}_{34} \mathrm{NO}_{5} \mathrm{P}$ & Sphingosine 1-phosphate & \\
\hline 31 & 504.273 & 503.2662 & 30.052 & $\mathrm{C}_{28} \mathrm{H}_{40} \mathrm{O}_{8}$ & Taxusin & \\
\hline 32 & 106.041 & 105.0492 & 30.173 & $\mathrm{C}_{6} \mathrm{H}_{5} \mathrm{CHO}$ & Benzaldehyde & \\
\hline 33 & 388.116 & 387.1081 & 30.208 & $\mathrm{C}_{20} \mathrm{H}_{20} \mathrm{O} 8$ & $3,6,7,3^{\prime}, 4^{\prime}$-Pentamethylquercetagetin & \\
\hline 34 & 372.142 & 371.1345 & 30.297 & $\mathrm{C}_{17} \mathrm{H}_{24} \mathrm{O}_{9}$ & Syringin & [19] \\
\hline 35 & 132.057 & 131.0646 & 30.798 & $\mathrm{C}_{9} \mathrm{H}_{8} \mathrm{O}$ & Cinnamaldehyde & \\
\hline 36 & 169.082 & 168.0896 & 30.898 & $\mathrm{C}_{9} \mathrm{H}_{11} \mathrm{NO}_{4}$ & L-Dihydrophenylalanine & \\
\hline 37 & 252.172 & 251.1791 & 31.638 & $\mathrm{C}_{15} \mathrm{H}_{24} \mathrm{O}_{3}$ & 3-Hydroxylubimin & \\
\hline 38 & 273.193 & 272.2012 & 31.616 & $\mathrm{C}_{15} \mathrm{H}_{23} \mathrm{~N}$ & 1-(p-Butylphenyl)-2,2-dimethyl-4,6-diamino-1,2-dihydro-s-Triazine & \\
\hline 39 & 338.138 & 337.1454 & 31.837 & $\mathrm{C}_{20} \mathrm{H}_{20} \mathrm{NO}_{4}^{+1}$ & Jatrorrhizine & \\
\hline 40 & 440.204 & 399.2115 & 32.834 & $\mathrm{C}_{22} \mathrm{H}_{32} \mathrm{O}_{9}$ & 10-Deacetyl-2-debenzoylbaccatin III & \\
\hline 41 & 518.253 & 517.2619 & 35.686 & $\mathrm{C}_{25} \mathrm{H}_{44} \mathrm{O}_{7} \mathrm{P}_{2}$ & Geranylfarnesyl diphosphate & \\
\hline 42 & 186.067 & 185.0755 & 35.887 & $\mathrm{C}_{12} \mathrm{H}_{10} \mathrm{O}_{2}$ & 3,5-Dihydroxybiphenyl & \\
\hline 43 & 504.253 & 503.2608 & 36.186 & $\mathrm{C}_{28} \mathrm{H}_{37} \mathrm{FO}_{7}$ & $\beta$-Methasone dipropionate & \\
\hline 44 & 368.125 & 367.1322 & 37.257 & $\mathrm{C}_{21} \mathrm{H}_{20} \mathrm{O}_{6}$ & Curcumin & \\
\hline 45 & 287.151 & 286.1581 & 40.314 & $\mathrm{C}_{17} \mathrm{H}_{21} \mathrm{NO}_{3}$ & Galanthamine & \\
\hline 46 & 431.303 & 430.3100 & 41.630 & $\mathrm{C}_{26} \mathrm{H}_{41} \mathrm{NO}_{4}$ & Malyngamide $\mathrm{H}$ & \\
\hline
\end{tabular}

MW: molecular weight; RT: retention times; MF: molecular formula. Compounds were tentatively identified based on accurate $m / z$, standards from PlantCyc (10 ppm) database, METLIN Mass Spectral Database, and literature data. 
<smiles>Cc1cc(O)c2c(c1)OC(c1ccc(O)c(O)c1)C(C)C2</smiles>

1

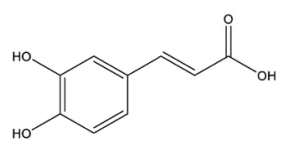

4

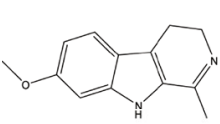

7

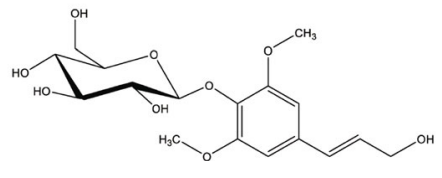<smiles>Cc1ccc(/C=C/C(=O)CC(=O)/C=C/c2ccc(C)c(O)c2)cc1C</smiles>

2<smiles>Cc1cc(C2Oc3cc(O)cc(C)c3C(=O)C2C)cc(I)c1O</smiles>

5

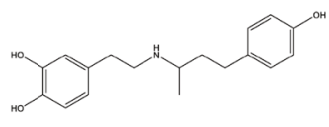

8

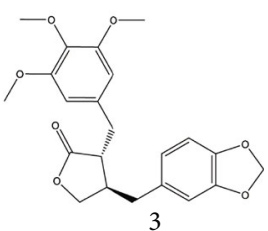

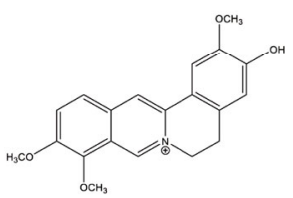

6

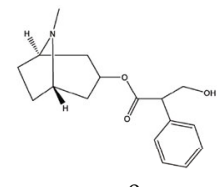

9

Figure 6: The chemical structures of some well-known identified anticancer compounds.

inhibiting NF- $\kappa$ B and AP-1 activity in cancer cells [30, 31], and syringin exhibited anticancer effects in HeLa human cervical cancer cells by inducing apoptosis, cell cycle arrest, and inhibition of cell migration [32]. The active ingredients identified in IC-MeOH are cytotoxic through apoptosis induction and cell cycle arrest. These reported findings correlate our investigations on the anticancer properties of IC$\mathrm{MeOH}$. The cytotoxicity and apoptosis assays of IC-MeOH revealed that IC-MeOH displayed a concentration- and time-dependent cytotoxicity against all the tested cell lines. Moreover, IC-MeOH inhibited the ability of CaSki cells to form colonies. The potential activity of a test substance such as a plant extract or secondary metabolite against cancer is not only associated with the cytotoxic or antiproliferative effect but is also related to the ability to inhibit mechanism concerning cancer's hallmarks [33]. The primary goal of anticancer chemotherapeutic drugs is to destroy cancer cells by inducing apoptosis in affected cells [34]. Apoptosis is a highly systematic and programmed cell death, wherein the cell debris is phagocytosed by the adjacent cells; the plant bioactive chemicals have molecular target for inducing apoptosis in different cancer cells [35-37]. In our study, IC$\mathrm{MeOH}$ was found to significantly induced apoptosis in CaSki cells after $24 \mathrm{~h}$ and $48 \mathrm{~h}$ of treatment at $\mathrm{IC}_{50}$ and $2 \mathrm{IC}_{50}$ values. IC- $\mathrm{MeOH}$ was also found to induce G0/G1 cell cycle arrest in CaSki after $24 \mathrm{~h}$ and $48 \mathrm{~h}$ of treatment periods. These outcomes correlate with previous investigations carried out on this plant species, which revealed its in vitro cytotoxicity, apoptosis-induced and G0/G1 cell cycle arrest against other types of cancer, including breast cancer, blood cancer, and human liver hepatocellular carcinoma [9]. Cell cycle checkpoints can be activated by DNA damage. In this case, the growth arrest caused by checkpoints allows the cell to repair the damage. If the damage is severe and cannot be repaired, mitochondrial mechanisms kick in to convert the cell cycle arrest signal into apoptotic signal, where p53 directly and indirectly through Bax targets mitochondrial membrane potential [38]. Furthermore, cell cycle arrest in response to DNA damage activates p53 and causes a G1 arrest by inducing expression of p21 and the consequent inhibition of cyclin D/Cdk [39]. Hence, the anticancer chemicals identified in IC-MeOH may be responsible for its cytotoxicity via induced apoptosis and G0/G1 cell cycle arrest toward cervical cancer cells. Results displayed by Figure 1 and Table 1show higher cytotoxicity of IC-MeOH toward nontumor cells than cancer cells that could represent adverse effects. Nonetheless, our previous investigations on IC-MeOH regarding its toxicity in vivo revealed nontoxic effects for acute and repeated administration [40]. To the best of our knowledge, the present study is highlighting for the first time the antiproliferative mode of action of IC$\mathrm{MeOH}$ toward human cervical cancer cells.

The use of herbal medicinal products for treating cancer is gaining acceptance, and many formulations have been patented and tested at the clinical trial stage.

\section{Conclusion}

The use of herbal medicinal products for treating cancer is gaining acceptance, and many formulations have been patented and tested at the clinical trial stage. The overall results provide promising baseline information to deeply investigate 
IC-MeOH's secondary metabolites for their anticancer activities. The UHPLC-HRMS analysis of IC-MeOH revealed the presence of anticancer chemicals belonging to various classes, which may be responsible for the cytotoxicity via apoptosis induction and G0/G1 cell cycle arrest shown by IC$\mathrm{MeOH}$ toward cervical cancer cells.

\section{Data Availability}

The datasets used and/or analyzed during the current study are available from the corresponding authors on reasonable request.

\section{Conflicts of Interest}

The authors declare no conflict of interest.

\section{Authors' Contributions}

V.K., S.K., S.M., and M.T.A. designed the study. N.P. performed the experimental work and wrote the manuscript. S.M. revised the manuscript. All authors have reviewed the manuscript.

\section{Acknowledgments}

The World Academy of Science (TWAS) and Department of Biotechnology (DBT) of India are acknowledged for the award of DBT-TWAS fellowship. The BD-NCBS (TIFR)iNStem Centre of Excellence in Flow Cytometry, Central Imaging and Flow Cytometry Facility (CIFF), and the Mass Spectrometry Facility of Centre for Cellular and Molecular Platforms (C-CAMP)/NCBS-TIFR for the different analysis. We would like to acknowledge the National Cancer Research Institute (NCCRI) for providing us with HCK1T cells.

\section{Supplementary Materials}

Table S1: UHPLC-HRMS instrumentation method for the HILIC phase. Table S2: UHPLC-HRMS instrumentation method for the reverse phase. (Supplementary Materials)

\section{References}

[1] World Health Organization (WHO) et al.November 2020, https://www.who.int/health-topics/cervical-cancer\#tab=tab_ 1.

[2] L. Zhu, X. Zheng, Y. Du, Y. Xing, K. Xu, and L. Cui, "Matrix metalloproteinase-7 may serve as a novel biomarker for cervical cancer," Oncogical Targeted Therapy, vol. 11, pp. 42074220, 2018.

[3] R. Oun, Y. E. Moussa, and N. J. Yewheate, "The side effects of platinum-based chemotherapy drugs: a review for chemist," Dalton Transaction, vol. 45, pp. 6645-6653, 2018.

[4] A. T. Mbaveng, V. Kuete, and T. Efferth, "Potential of Central, Eastern and Western Africa medicinal plants for cancer therapy: spotlight on resistant cells and molecular targets," Frontiers in Pharamacology, vol. 8, no. 43, 2017.

[5] M. Narayani and S. Srivastava, "Elicitation: a stimulation of stress in in vitro plant cell/tissue cultures for enhancement of secondary metabolite production," Phytochemistry Reviews, vol. 16, no. 6, pp. 1227-1252, 2017.

[6] V. Cheynier, G. Comte, K. M. Davies, V. Lattanzio, and S. Martens, "Plant phenolics: recent advances on their biosynthesis, genetics, and ecophysiology," Plant Physiology Biochemistry, vol. 72, pp. 1-20, 2013.

[7] J. T. Arnason, R. Mata, and J. T. Romeo, Phytochemistry of Medicinal Plants, Springer Science \& Business Media. Springer, New York, USA, 1995th Ed edition, 2013.

[8] V. Kuete, B. Krusche, B. Youns et al., "Cytotoxicity of some Cameroonian spices and selected medicinal plant extracts," Journal of Ethnopharmacology, vol. 134, no. 3, pp. 803-812, 2011.

[9] V. Kuete, L. P. Sandjo, B. Wiench, and T. Efferth, "Cytotoxicity and modes of action of four Cameroonian dietary spices ethno- medically used to treat cancers: Echinops giganteus, Xylopia aethiopica , Imperata cylindrica and Piper capense," Journal of Ethnopharmacology, vol. 149, no. 1, pp. 245-253, 2013.

[10] P. Nayim, A. T. Mbaveng, M. Sanjukta, J. Rikesh, V. Kuete, and K. Sudhir, "CD24 gene inhibition and TIMP-4 gene upregulation by Imperata cylindrica's root extract prevents metastasis of CaSki cells via inhibiting PI3K/Akt/snail signaling pathway and blocking EMT," Journal of Ethnopharmacology, vol. 275, no. 114111, 2021.

[11] R. Keshava, N. Muniyappa, G. Rajalakshmi, and A. S. Ramaswamaiah, "Anti-cancer effects of Imperata cylindrica leaf extract on human oral squamous carcinoma cell line SCC-9 in vitro," Asian Pacific Journal of Cancer Prevention, vol. 17, no. 4, pp. 1891-1898, 2016.

[12] A. H. Y. Kwok, Y. Wang, and W. S. Ho, "Cytotoxic and prooxidative effects of Imperata cylindrica aerial part ethyl acetate extract in colorectal cancer in vitro," Phytomedicine, vol. 23, no. 5, pp. 558-565, 2016.

[13] K. Dettmer, P. Aronov, and B. Hammock, "Mass spectrometry-based metabolomics," Mass Spectrometry Reviews, vol. 26, no. 1, pp. 51-78, 2007.

[14] P. Ramakrishnan, S. Nair, and K. Rangiah, "A method for comparative metabolomics in urine using high resolution mass spectrometry," Journal of Chromatography A, vol. 1443, pp. 83-92, 2016.

[15] B. S. Katarzyna and M.-O. Elżbieta, "Biological evaluation of the activity of some benzimidazole-4, 7-dione derivatives," Molecules, vol. 19, pp. 15361-15373, 2014.

[16] N. A. Franken, H. M. Rodermond, J. Stap, J. Haveman, and V. C. Bree, "Clonogenic assay of cells in vitro," Natural Protocol, vol. 1, no. 5, pp. 2315-2319, 2006.

[17] M. Azizi, H. Ghourchian, F. Yazdian, F. Dashtestani, and H. Alizadeh Zeinabad, "Cytotoxic effect of albumin coated copper nanoparticle on human breast cancer cells of MDAMB 231," PLoS One, vol. 12, article e0188639, 2017.

[18] K. Pumiputavon, T. Chaowasku, C. Saenjum et al., "Cell cycle arrest and apoptosis induction by methanolic leaves extracts of four Annonaceae plants," BMC Complementary and Alternative Medicine, vol. 17, no. 294, 2017.

[19] P. V. Fernando, I. M. Olivares-Corichi, A. G. Perez-Ruiz, J. O. Luna-Arias, and J. R. García-Sánchez, "Apoptosis induced by (-)-epicatechin in human breast cancer cells is mediated by reactive oxygen species," Molecules, vol. 25, no. 5, 2020.

[20] M. Singh and N. Singh, "Molecular mechanism of curcumin induced cytotoxicity in human cervical carcinoma cells," 
Molecular and Cellular Biochemistry, vol. 325, pp. 107-119, 2009.

[21] A. Allegra, V. Innao, S. Russo, D. Gerace, A. Alonci, and C. Musolino, "Anticancer activity of curcumin and its analogues: preclinical and clinical studies," Cancer Investigation, vol. 35, pp. 1-22, 2017.

[22] W. T. Zang, Y. Wang, M. Wang et al., "Myricetin exerts antiproliferative, anti-invasive, and pro-apoptotic effects on esophageal carcinoma EC9706 and KYSE30 cells via RSK2," Tumor Biology, vol. 35, no. 12, pp. 12583-12592, 2014.

[23] J. X. Feng, Y. Chen, Y. Wang, Q. Du, W. Sun, and G. Z. Zang, "Myricetin inhibits proliferation and induces apoptosis and cell cycle arrest in gastric cancer cells," Molecular and Cellular Biochemistry, vol. 408, no. 1-2, pp. 163-170, 2015.

[24] J. L. Yi, S. Shi, Y. L. Shen et al., "Myricetin and methyl eugenol combination enhances the anticancer activity, cell cycle arrest and apoptosis induction of cis-platin against HeLa cervical cancer cell lines," International Journal of Clinical and Experimental Pathology, vol. 8, no. 2, pp. 1116-1127, 2015.

[25] S. T. Ho, C. C. Lin, Y. T. Tung, and J. H. Wu, "Molecular mechanisms underlying yatein-induced cell-cycle arrest and microtubule destabilization in human lung adenocarcinoma cells," Cancers, vol. 11, no. 1384, 2019.

[26] G. Kanimozhi and N. R. Prasad, "Anticancer effect of caffeic acid on human cervical cancer cells," in Coffee in Health and Disease Prevention, Academic Press, 2015.

[27] R. Liu, Z. Cao, Y. Pan, and G. Zhang, "Jatrorrhizine hydrochloride inhibits the proliferation and neovascularization of C8161 metastatic melanoma cells," Anti-Cancer Drugs, vol. 24, no. 7, pp. 667-676, 2013.

[28] Y. Ding, J. He, J. Huang et al., "Harmine induces anticancer activity in breast cancer cells via targeting TAZ," International Journal of Oncology, vol. 54, no. 6, pp. 1995-2004, 2019.

[29] J. Yin, Q. Dong, M. Zheng et al., "Antitumor activity of dobutamine on human osteosarcoma cells," Oncological Letters, vol. 11, no. 6, pp. 3676-3680, 2016.

[30] C. W. Lee, S. H. Lee, J. W. Lee et al., "2-Hydroxycinnamaldehyde inhibits SW620 colon cancer cell growth through AP-1 inactivation," Journal of Pharmacological Sciences, vol. 104, no. 1, pp. 19-28, 2007.

[31] C. M. Cabello, B. B. Warner, S. D. Lamore et al., "The cinnamon-derived Michael acceptor cinnamic aldehyde impairs melanoma cell proliferation, invasiveness, and tumor growth," Free Radical Biology and Medicine, vol. 46, no. 2, pp. 220-231, 2009.

[32] N. Xia, "Syringin exhibits anticancer effects in HeLa human cervical cancer cells by inducing apoptosis, cell cycle arrest and inhibition of cell migration," Bangladesh Journal Pharmacology, vol. 11, no. 4, pp. 838-843, 2016.

[33] D. Hanahan and R. A. Weinberg, "Hallmarks of cancer: the next generation," Cell, vol. 144, 2011.

[34] R. K. Singh, A. Ranjan, A. K. Srivastava et al., "Cytotoxic and apoptotic inducing activity of Amoora rohituka leaf extracts in human breast cancer cells," Journal of Ayurveda and Integretive Medicine, vol. 11, pp. 383-390, 2020.

[35] S. M. Pacifico, P. Gallicchio, N. Lorenz et al., "Apolar Laurus nobilis leaf extracts induce cytotoxicity and apoptosis towards three nervous system cell lines," Food Chemical Toxicology, vol. 62, pp. 628-637, 2013.

[36] K. Suresh, S. K. Vinay, Y. Savita, and S. Dey, "Antiproliferative and apoptotic effects of black turtle bean extracts on human breast cancer cell line through extrinsic and intrinsic pathway," Chemistry Central Journal, vol. 11, no. 56, 2017.

[37] M. Majumder, S. Debnath, R. L. Gajbhiye et al., "Ricinus communis L. fruit extract inhibits migration/invasion, induces apoptosis in breast cancer cells and arrests tumour progression in vivo," Scientific Report, vol. 9, no. 14493, 2019.

[38] A. H. Wyllie, "Apoptosis: an overview," British Medical Bulletin, vol. 53, no. 3, pp. 451-465, 1997.

[39] E. Schneider, M. Montenarh, and P. Wagner, "Regulation of CAK kinase activity by p53," Oncogene, vol. 17, no. 21, pp. 2733-2741, 1998.

[40] P. Nayim, A. T. Mbaveng, A. M. Ntyam, and V. Kuete, "A botanical from the antiproliferative Cameroonian spice, Imperata cylindrica is safe at lower doses, as demonstrated by oral acute and sub-chronic toxicity screenings," BMC Complementary Medicine and Therapy, vol. 20, no. 273, 2020.

[41] A. Hyo-Jin, A. Nugroho, B. M. Song, and H. J. Park, "Isoeugenin, a novel nitric oxide synthase inhibitor isolated from the rhizomes of Imperata cylindrica," Molecules, vol. 20, pp. 21336-21345, 2015.

[42] F. Gebashe, A. O. Aremu, J. Gruz, J. F. Finnie, and J. V. Staden, "Phytochemical profiles and antioxidant activity of grasses used in South African traditional medicine," Plants, vol. 9, no. $371,2020$. 